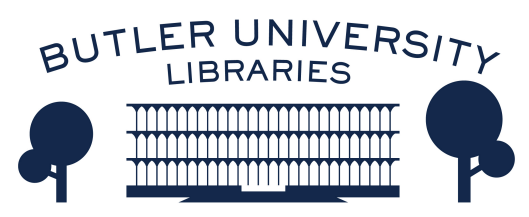

Journal of Hindu-Christian Studies

Volume 6

Article 5

January 1993

\title{
The New Master-Paradigm: Ecology
}

\author{
Klaus Klostermaier
}

Follow this and additional works at: https://digitalcommons.butler.edu/jhcs

Part of the Religion Commons

\section{Recommended Citation}

Klostermaier, Klaus (1993) "The New Master-Paradigm: Ecology," Journal of Hindu-Christian Studies: Vol. 6, Article 5.

Available at: https://doi.org/10.7825/2164-6279.1074

The Journal of Hindu-Christian Studies is a publication of the Society for Hindu-Christian Studies. The digital version is made available by Digital Commons @ Butler University. For questions about the Journal or the Society, please contact cbauman@butler.edu. For more information about Digital Commons @ Butler University, please contact digitalscholarship@butler.edu. 


\title{
The New Master-Paradigm:
}

\author{
Ecology
}

\section{Klaus Klostermaier}

\author{
University of Manitoba
}

THE THESIS OF this essay is that ecology, understood as concern for nature in the most comprehensive sense, is going to be the master paradigm of the science and politics of the future. It will not only be the focus of theoretical preoccupations aiming at halting, and possibly reversing the destructive tendencies inherent in modern industrial civilisation but also the focus of socio-political praxis: no government will be able to survive if it does not give concrete expression to the ecological concern of its citizens and the ecological focus will bring about a cooperation of people across the boundaries of nationality, race, language, class and caste. Ecology will be the fulcrum of an ethics of the future, an ethics as compellingly evident to individuals as enforceable with corporations, accepted by governments and international agencies as condition of survival. As such, an ecological ethics, or better, an ethics based on ecology, will require the contributions of all. It requires the day-to-day diligence of every human being on earth, the exercise of care and the imaginative nurture of nature. It requires the attention of those who are in positions of responsibility at all levels of government, so as to make sure that environmental concerns becomes an enforceable and enforced policy. It requires the attention of scientists, who, having found the means to exploit and despoil nature, must now apply their skills and their knowledge to finding ways to restore and preserve nature.
It also requires the attention of the humanists, who for too long have taken nature for granted and have left it to the more practical people in government and industry to provide for the mundane necessities of life, so that they could dwell in the more refined realm of culture and art. It requires the attention of students of religions, too. Students (and often practitioners) of religions, especially if they come from a (modern) Christian background, often not only made a theoretical distinction between the natural and the supernatural, but also took this to be an evaluation and the basis for their theoretical and practical concerns. Nature was considered not only lower, as compared to supernature, it was also considered fallen, corrupt, the opposite to spirit, the domain of the devil, the darkness which had to be overcome, the force which drew one away from God. The concern of the religious person was the supernatural, a God transcendent and a life beyond. Christianity in particular (as Judaism before), encountering tribal traditions, in which nature, or aspects of nature, were worshipped expressed itself in an often fiercely nature-hostile way. The apostles of Christianity in Europe gloried in cutting down trees sacred to Thor and Wotan, in destroying mountain sanctuaries devoted to Apollo and Jupiter, vandalising groves supposed to be the dwelling places of semigods and in general discouraging people from entering into any deeper emotional relationship with nature, even teaching 'agere 


\section{Klaus Klostermaier}

contra naturam' as the highest principle of Christian ethics. The novelty and uniqueness of Christianity was interpreted as a need to cut off all ties with past practice and belief, practices and beliefs which more often than not had nature as their object.

Many influential religious traditions have a substantial environmental ethics. It appears also important for a future environmental ethics to connect with what was called 'conscience' in the West and not to suggest that it is a matter of convention, aesthetics, preferences and the like, which has characterised much of recent ethics discussion in other areas. This has two consequences.

The first is that those people who consider themselves religious must include in their religious theory and practice care for nature. They can no longer maintain their dichotomy of nature/supernature and leave this world to the devil, while saving souls for the next. The religious conscience must include concern for nature, as it did in such famous Christians as Francis of Assisi.

The second is that ecological ethics must connect with some sort of an ultimate: it is not enough to drive ecological ethics from a cost-benefit calculus or to criminalise environmental offences. We must go beyond pragmatism and opportunistic politicking. We have to recognise that there is only one earth, and if we do not preserve it, there will be none. Utopias of space-colonies are, for the foreseeable future, just that: utopias, nowheres. At present one cannot imagine to send even a sizable fraction of the more than 6 billion people living on earth into any space world. In the sense in which this earth is, for us here and now, an ultimate and a singularity, its preservation constitutes, in traditional categories, something 'sacred'.

Ecology also has implications for ethics in the traditional sense which concerned itself exclusively with human persons and human societies. In spite of progress in many areas which permits a much larger number of people to derive physical sustenance from the same area, there is a limit and there is a need to allocate limited resources fairly among all.

Last, but not least, an increasing number of religious thinkers devote attention to environmental ethics and an impressive body of writing is emerging, from within all major religious traditions, drawing ecological conclusions from central tenets of faiths. Let it be stated at the end that I do not contrast 'faith' with 'reason', as has been done for so long, especially in the West, but that I consider reason as inalienably human and 'religious' as I consider faith the foundation for any human enterprise of consequence. A contemporary ecology will require faith faith in the worthwhileness of saving the environment, faith in the ability and willingness of humans to do so - and reason - the rationality of economics as well as of science, of philosophy and of theology. 